\title{
Workplace Monitoring and the Right to Private Life at Work
}

\author{
Joe Atkinson*
}

In Barbulescu v Romania, the European Court of Human Rights clarified the application of the Article 8 right to private life in the workplace, and the extent of the state's positive obligations to protect the right against workplace monitoring. The decision establishes that there is an irreducible core to the right to private life at work that does not depend on an employee's reasonable expectations of privacy, and sets out clear principles for striking a fair balance between Article 8 and the employer's interests in the context of workplace monitoring. This article considers the nature of states' positive obligation to protect human rights at work, the scope of the right to private life, and the impact of the decision on domestic law of unfair dismissal.

Keywords: Human Rights, Employment, European Court of Human Rights, Article 8, Private life

\section{Introduction}

The position of authority and control held by employers creates a risk that they might interfere with the human rights of their employees. The increasing use of technology in workplaces makes this danger particularly acute in respect of the right to private life. ${ }^{1}$ Twenty years after the European Court of Human Rights (ECtHR or Court) first found the right to private life

\footnotetext{
*University College London. An early draft of this paper was presented to the UCL Public Law Group, and I thank Jeff King for the opportunity as well as all those present for their helpful comments. I am also grateful to the anonymous reviewer. Any errors remain entirely my own.

${ }^{1}$ S. Wallach, 'The Medusa Stare: Surveillance and Monitoring of Employees and the Right to Privacy' (2011) 27

Int'I J. Comp. Lab. L. \& Indus. Rel. 189; M. Finkin, R. Krause and H. Takeuchi-Okuno, 'Employee Autonomy, privacy and dignity under technological oversight' in M. Finkin and G. Mundlak, Comparative Labor Law (Edward Elgar Publishing 2015); A. Spicer, 'Surveillance Used to Be a Bad Thing. Now, We Happily Let Our Employers Spy on Us' (The Guardian), at http://www.theguardian.com/commentisfree/2017/aug/04/surveillance-employers-spy-implanted-chipped (last accessed 27 October 2017).
} 
under Article 8 of the Convention covered workplace monitoring ${ }^{2}$ their decision in Barbulescu v Romania ${ }^{3}$ extends the application of Article 8 at work, and establishes a positive obligation on states to safeguard employees' right to private life from monitoring by employers. This note sets out the facts of the case and the reasoning of the Court, before considering three key issues it raises; the nature and extent of the positive obligation to protect private life at work, the role of reasonable expectations in determining the scope of Article 8, and the significance of Barbulescu for the English law of unfair dismissal.

\section{Facts}

Mr Barbulescu was employed as a sales engineer, and was required to create a Yahoo messenger account for work purposes. Internal regulations, which he had signed, prohibited personal use of computers but did not expressly mention monitoring. In July 2007 an information notice was circulated which reiterated this ban, and stated that employees would be monitored. It also drew attention to the fact that someone had recently been fired for personal use of her computer. At some point between the third and thirteenth of July $\mathrm{Mr}$ Barbulescu signed a copy of this notice. From the fifth to thirteenth of July his Yahoo account was monitored in real time. At the end of this period he was informed that his internet usage was significantly higher than his colleagues, and asked to explain his personal use of the messenger account. When Mr Barbulescu denied any personal use his employer provided him with a 45-page transcript of his messages. This included correspondence with his brother and

\footnotetext{
${ }^{2}$ Halford v UK [1997] ECHR 32; see also Copland v UK [2007] ECHR 253.

${ }^{3}$ [2017] IRLR 1032 .
} 
fiancée, some of which concerned extremely personal and intimate matters. He was dismissed shortly afterwards on misconduct grounds for breaching the company's rules on personal use of computers.

The Romanian courts rejected Mr Barbulescu's claim for unfair dismissal, finding that the decision to dismiss him was lawful. The Court of Appeal considered the argument that the dismissal should be illegal because it interfered with Mr Barbulescu's Article 8 right to private life. In doing this they balanced the employers' right to monitor, which was treated as coming within their right to supervise work, against the employee's right to private life and found that the principles of necessity and proportionality, as set out in EU Data Protection Directive, ${ }^{4}$ had been complied with. The court concluded that it had been necessary for the employer to access the content of the messages to prove personal use during the disciplinary process, and that this was done in pursuit of the legitimate aim of supervising staff performance and ensuring the smooth running of the company.

Following this the case was brought before the ECtHR, with Mr Barbulescu arguing that the Romanian court's failure to find his dismissal unlawful breached the state's positive duties to protect his right to 'private and family life, his home and his correspondence' under Article 8 of the Convention. The key questions before the Court were whether Article 8 was engaged in these circumstances, and if so, whether there had been a failure to 'secure to everyone within their jurisdiction the rights and freedoms defined in...[the] Convention' as required by Article 1 of the Convention.

\footnotetext{
${ }^{4}$ No. 95/46/EC.
} 


\section{Decisions of the Chamber and Grand Chamber}

The claim initially failed in the $4^{\text {th }}$ Section Chamber of the ECtHR. The majority of the Court found that the Romanian court had struck an appropriate balance between the rights of the employee and employer. They had been entitled to find that it was necessary and proportionate for the employer to access the communications during the disciplinary process to determine whether there had been personal use in breach of company rules. The Court also stressed that it is not unreasonable for an employer to want to verify that employees are completing professional tasks during work hours. The decision generated a sizeable reaction from the UK press, with several papers reporting that the case had recognised a right for employers to spy on workers. This in turn prompted the Council of Europe to condemn the 'misinformed media storm' which had followed the decision. ${ }^{5}$

On appeal to the Grand Chamber there was a split decision as to whether the state had breached its positive obligations under Article 8. However, the Court was united in finding that the right to private life was applicable in the circumstances. The Romanian Government had argued that Article 8 was not engaged as there was no reasonable expectation of privacy. They distinguished the present facts from previous cases as the messenger account was created for work purposes, personal use had been forbidden and Mr Barbulescu had been warned that monitoring was in place. In response to this, the Court stated that the existence of a reasonable expectation of privacy is 'a significant but not necessarily conclusive factor'

\footnotetext{
${ }^{5} \mathrm{~K}$. Rawlinson, 'UK press accused of 'misinformed media storm' over email spying story' (The Guardian), at https://www.theguardian.com/technology/2016/ian/16/uk-press-accused-of-misinformed-media-storm-overemail-spying-story (accessed 19th October 2017).
} 
when determining whether Article 8 was engaged. ${ }^{6}$ In this instance Mr Barbulescu was aware of the ban on private use, but it was unclear whether he was informed that monitoring might be in place prior to it happening, and he had certainly not been informed of the nature or extent of the monitoring. The majority believed that it was 'open to question' whether $\mathrm{Mr}$ Barbulescu had a reasonable expectation of privacy in these circumstances. However, they stated that 'an employer's instructions cannot reduce private social life in the workplace to zero. Respect for private life and for the privacy of correspondence continues to exist, even if these may be restricted in so far as necessary'. ${ }^{7}$ They found that Article 8 was applicable as the communications came within the concepts of private life and correspondence. The broad nature of the right to private life was emphasised in reaching this conclusion. Article 8 protects the ability to develop one's social identity and relationships with others, ${ }^{8}$ and can include matters within a person's professional life because 'it is in the course of their working lives that the majority of people have a significant, if not the greatest, opportunity to develop relationships' ${ }^{9}$ The Court also noted that the reference to correspondence in the text of Article 8 does not have 'private' as a qualifying adjective, unlike the reference to life, and that previous case law did not distinguish between private and professional communications when finding that communications from business premises may be covered by Article $8 .{ }^{10}$ The

\footnotetext{
${ }^{6}$ n 3 above,73, citing Köpke v Germany ECtHR 5 Oct 2010.

7 ibid at [80].

8 ibid at [70].

${ }^{9}$ ibid at [71], citing Niemietz v Germany [1992] ECHR 80.

10 ibid at [72].
} 
minority judgement agreed with this analysis and concluded that Article 8 was applicable, despite it being 'difficult to see' how a reasonable expectation of privacy could exist. ${ }^{11}$

Once Article 8 was found to be engaged the Court addressed the 'nature and scope' of the state's positive obligation to ensure effective respect for rights protected by Article $8 .{ }^{12}$ It is at this point that the majority and minority positions diverge. The majority stated that while a wide margin of appreciation must be given to states in assessing the need to establish a legal framework in this area, this discretion 'cannot be unlimited' and States must ensure adequate safeguards are in place to deal with workplace monitoring. ${ }^{13}$ In their view the positive obligation under Article 8 required the domestic courts to strike a fair balance when weighing the right to private life against the interests of the employer. In contrast, the dissenting judges thought that it was wrong for the majority to focus narrowly on the balance struck by the domestic court; what mattered was the adequacy of the domestic legal framework as a whole, rather than the balance struck in any particular area of that framework. They argued that this followed from the discretion states have over the means used for creating 'an adequate "legal framework" affording protection to the victim'. ${ }^{14}$ The minority pointed out that other civil and criminal law avenues were available to $\mathrm{Mr}$ Barbulescu, and thought that there could be no basis for finding a violation without an assessment that the entire national framework cumulatively failed to protect Article $8 . .^{15}$

\footnotetext{
11 ibid at dissenting judgement [1].

12 ibid at [114].

13 ibid at [120].

${ }^{14}$ ibid at dissenting judgement [5].

15 ibid at dissenting judgement [7-17].
} 
Having concluded that the national court needed to strike a fair balance between the right to private life and the employer's interests, the majority set out the general principles for assessing this question. ${ }^{16}$ These were also accepted by the dissenting judgement. ${ }^{17}$ The Court stated that it is 'essential' that monitoring be proportionate, and identified several factors that domestic authorities must treat as relevant when considering this; ${ }^{18}$

1. that advance notification, including about the nature of monitoring, will normally be required for monitoring to be compatible with Article 8;

2. the extent of monitoring and its intrusiveness, with a distinction between monitoring the flow of communications and accessing their content;

3. whether the employer has provided a legitimate reason justifying the monitoring;

4. the consequences of monitoring for the employee, and whether the monitoring was used solely for the stated legitimate aim;

5. whether procedural safeguards were in place ensuring that the content of communications could not be accessed without the employee being notified in advance of this possibility

In addition, there must be access to a judicial body capable of scrutinising whether these criteria had been observed.

When assessing whether the domestic court had acted in line with these principles, the Court found that the interests at stake and relevant principles had been correctly identified, but there

\footnotetext{
${ }^{16}$ ibid at [113-122].

17 ibid at dissenting judgement [1].

18 ibid at [121].
} 
were substantial flaws in the balancing exercise conducted. There had been insufficient attention paid to whether monitoring had begun before notification, the absence of notice about the nature or extent of monitoring, or the possibility that the content might have been accessed without Mr Barbulescu's knowledge. When striking the balance the national court also failed to identify a sufficiently specific aim to justify monitoring and did not consider the scope of monitoring and degree of intrusion, the seriousness of the consequences, or whether the aim could have been achieved by less intrusive methods. These shortcomings meant that the domestic court had failed to strike a fair balance between the interests at stake, meaning there was inadequate protection afforded to the right to private life. The Court declined to award damages however, as the judgement itself was thought to provide just satisfaction.

The dissenting judges thought that even if it were appropriate to focus narrowly on the balance struck by the domestic employment court there was no breach of Article 8, because the domestic court's choice to prioritise the employer's interests came within the State's margin of appreciation. In their view the domestic court had carried out a careful balancing exercise and found that the monitoring was the only way for the employer to achieve the legitimate aim of ensuring smooth running of the company.

\section{The nature and extent of positive obligations under Article 8}

As Barbulescu concerned monitoring undertaken by a private individual (the employer), rather than the state, the Court had to determine the nature and extent of the state's positive obligation under Article 8. The Grand Chamber set out clear requirements for how domestic legal systems should protect the right to private life in the context of workplace monitoring. These included both substantive elements, such as the type of notification that is generally 
needed, and procedural safeguards, such as the relevant factors to consider when striking the balance. However, there was substantial disagreement over the correct approach to the question of positive obligations. Given this, it is worth considering the proper scope of positive obligations after Barbulescu.

The minority took the view that because states have discretion over the means of fulfilling their positive obligations the Court must consider the legal system as a whole rather than focussing on a particular area of the framework. It is certainly true that states generally have the choice of how to fulfil their positive obligations; the Convention does not prescribe 'any given manner for ensuring within their internal law the effective implementation of any of the provisions of the Convention'. ${ }^{19}$ Nonetheless, there are exceptions to this where a states' positive obligation requires them to introduce specific legislation. In Siliadin v France and for example, the Court found that the absence of a criminal offence covering conditions of modern slavery was a breach of Article $4,{ }^{20}$ and in Redfearn $\mathrm{v} U K$ the Court specified the means that must be adopted by the state in the context of employment law. ${ }^{21}$ However, in Barbulescu the Court found that while safeguards were needed, these need not take any specific form. So the state continues to have discretion over how to fulfil its positive obligation in this area. The question is therefore, whether this discretion makes it illegitimate to consider the balance struck by the domestic court in isolation, rather than assessing the domestic legal framework in the round.

\footnotetext{
${ }^{19}$ Swedish Engine Drivers' Union v Sweden [1976] ECHR 2 at [50].

${ }^{20}$ [2005] ECHR 545; CN v UK [2012] ECHR 1911.

${ }^{21}$ [2012] ECHR 1878.
} 
The majority acknowledged that states have discretion as to the means by which Article 8 is protected, but nevertheless felt able to assess the balance struck by the domestic court without considering the wider legal framework. It would certainly be problematic if this position resulted in domestic employment courts having to duplicate protective mechanisms that exist elsewhere in the national legal framework. Furthermore, if every area of the legal framework must conduct a fair balancing exercise this effectively abolishes the state's freedom to choose the means for fulfilling their positive obligations. However, the majority decision can be defended on the basis that neither of these problems arise. The best interpretation of the Court's position is that the state retains the 'choice of means calculated to secure compliance with Article 8 (art. 8) in the sphere of relations of individuals between themselves', ${ }^{22}$ but that the means chosen to strike the balance between Article 8 and other interests must do so fairly. Therefore the Convention does not impose an obligation to introduce a specific form of protection against workplace monitoring, but where the domestic legal system does attempt to strike a balance on this issue it must ensure respect for Article 8. This is consistent with the view that the states choice over the 'ways and means' of meeting their positive obligation limits the Court's function 'to reviewing whether or not the particular solution adopted can be regarded as striking a fair balance'.$^{23}$ The majority judgement in Barbulescu perfectly embodies this approach. The domestic court was required to strike a fair balance between private life and the employer's interests because it was the means chosen by the state for striking this balance.

\footnotetext{
${ }^{22} X$ and $Y \vee$ The Netherlands (1986) 8 EHRR 235 at [24].

${ }^{23}$ Hatton v UK [2003] 37 EHRR 28 at [123].
} 
The view that the Court can legitimately assess the balance struck by each particular domestic framework that is used as the means for fulfilling a state's positive obligations under Article 8 , rather than having to consider the system as a whole, seems a sensible one. It leaves states with discretion over which areas of their legal framework should conduct the balancing exercise between private life and the employer's interests, but also ensures that any attempt to regulate this issue adequately respects the right to private life. This approach to positive obligations means that Barbulescu has potentially far-reaching implications for domestic law - any area of law which balances an employee's Article 8 right and an employers' interests in monitoring must do so in accordance with the principles set out in the case. In English law this includes the Human Rights Act 1998, the Data Protection Act 1998, the Investigatory Powers Act 2016, and the tort of 'misuse of private information' ${ }^{24}$ It is probable that these already largely reflect the criteria set out in Barbulescu, but a close evaluation might reveal shortcomings in the level of protection.

\section{Reasonable expectation of privacy}

One of the most notable aspects of the ECtHR's decision is the unanimous finding by the Grand Chamber that Article 8 was applicable in circumstances where it is hard to see how a reasonable expectation of privacy exists. The Court has previously stated that a reasonable expectation of privacy 'may be a significant, although not necessarily conclusive, factor' ${ }^{25}$ as

\footnotetext{
${ }^{24}$ G. Morris, 'Protection of Employees' Personal Information and Privacy in English Law' in R. Blanpain and H. Nakakubo, Protection of Employees' Personal Information and Privacy (Kluwer Law International 2014).

${ }^{25}$ P.G. and J.H. v United Kingdom [2001] ECHR 546; Peck v UK [2003] ECHR 44; Perry v UK 2003] ECHR 375; Uzun v Germany IHRL 1838 (ECHR 2010).
} 
to whether Article 8 is engaged. In practice however, the reasonable expectations test has been the main tool that the Court has used for defining the scope of Article 8 in the workplace. In both Halford $\mathrm{v} U K$ and Copland $\mathrm{v} U K$, cases which involved monitoring of telephone and electronic communications by public sector employers, the right to private life was found to be engaged largely because the lack of warning meant that the employees had a reasonable expectation of privacy. ${ }^{26}$ The reasonable expectations test has also been used as one of the main tools to determine the applicability of Article 8 in cases away from the workplace. ${ }^{27}$ It is therefore significant that the Court found the right to private life was engaged by workplace monitoring without finding that there was a reasonable expectation of privacy. This puts Strasbourg's view of Article 8 at odds with the approach currently taken in English law under both the Human Rights Act 1998 and the law of unfair dismissal, where the courts have refused to find that the right to private life can be engaged without a reasonable expectation of privacy. ${ }^{28}$

The reasonable expectation of privacy test is used to define the scope of the right to private life in claims brought under the Human Rights Act, with Laws LJ describing it as 'the touchstone for Article 8(1)'s engagement'. ${ }^{29}$ The question of whether Article 8 could be engaged without a reasonable expectation of privacy was considered directly by the Supreme

\footnotetext{
${ }^{26} \mathrm{n} 2$ above.

${ }^{27}$ Von Hannover v Germany [2004] ECHR 294.

${ }^{28}$ See also V. Mantouvalou, 'Human Rights and Unfair Dismissal: Private Acts in Public Spaces' (2008) 71 MLR

912.

${ }^{29} R$ (Wood) v Commissioner of Police of the Metropolis [2010] 1 WLR 123, 136.
} 
Court in In re JR38..$^{30}$ In that case a child claimed that his right to private life was interfered with when a photograph of him taking part in a riot was published in the local newspaper in order to identify him. The Supreme Court held that as there was no reasonable expectation of privacy there could be no interference with Article 8. Giving the majority decision, Lord Toulson stated that the ECtHR's endorsement of the reasonable expectations test when deciding the scope of Article 8 in Von Hannover superseded the statements in $P G$ and JH v UK that a reasonable expectation of privacy is not necessarily determinative of the issue. Lord Kerr entered a minority judgement, arguing in favour of other factors being considered in addition to reasonable expectations, as he believed that no principled reasons had been advanced for adopting reasonable expectations as the touchstone test.

The majority view in In re JR38, that Von Hannover established reasonable expectations as the sole criteria for determining whether Article 8 is engaged, was always questionable. The ECtHR has repeatedly reiterated the view that reasonable expectations are 'not necessarily conclusive', including after Von Hannover, ${ }^{31}$ and Purshouse points out that several cases have found that Article 8 is applicable without mention of the reasonable expectations test. ${ }^{32}$ The decision in Barbulescu confirms that Lord Kerr's judgement better reflects the view in Strasbourg that a reasonable expectation of privacy is not always necessary for Article 8 to be engaged. In the wake of Barbulescu the UK courts might be prompted by their obligation to have regard to ECtHR jurisprudence under s.2 of the Human Rights Act to move away from their current reliance on the reasonable expectations test in future cases involving Article 8.

\footnotetext{
${ }^{30}[2015]$ UKSC 42.

${ }^{31}$ Köpke v Germany ECtHR 5 Oct 2010; Uzun n 25 above.

32 J. Purshouse, 'The Reasonable Expectation of Privacy and the Criminal Suspect' (2016) 79 MLR 871, 880.
} 
The reasonable expectation test is also used to delineate the boundaries of the right to private life in cases of unfair dismissal. If a dismissal raises Article 8 issues this may impact on the Employment Tribunal's assessment of whether a dismissal is unfair, ${ }^{33}$ and the reasonable expectation test is used to determine whether the right to private life is engaged in this context. The case of Atkinson v Community Gateway Association provides a good illustration of the extent to which the English courts currently diverge from the ECtHR regarding the scope of private life at work. In Atkinson, an employee was dismissed for personal use of his work email account in contravention of the company rulebook, which also contained a warning that communications would be monitored. The Employment Appeal Tribunal (EAT) held that his employer accessing his email did not interfere with his private life; the employee must have been aware of the company policy as he himself had written it, so he could not have a reasonable expectation of privacy as required for Article 8 to be engaged. ${ }^{34}$ The EAT rejected the argument that reasonable expectations are not conclusive of the Article 8 question, saying 'we do not read [PG and $J H \mathrm{v} U K]$ as holding that Article 8 rights may be breached even where there is no reasonable expectation of privacy', and 'We have not seen anything in the authorities which suggests that Article 8 may be deployed where there is no reasonable expectation of privacy'. ${ }^{35}$ After Barbulescu, the situation in Atkinson must be recognised as raising Article 8 issues. In addition, tribunals should no longer rely solely on reasonable

\footnotetext{
${ }^{33}$ Xv Y [2004] EWCA Civ 662; H. Collins, 'The Protection of Civil Liberties in the Workplace' (2006) 69 MLR 619;

H. Oliver, 'Employment Law' in D. Hoffman (ed), The Impact of the UK Human Rights Act on Private Law (Cambridge University Press 2011).

${ }^{34}$ UKEAT/0457/12/BA.

35 ibid at [63].
} 
expectations when deciding the scope of private life at work, or accept that company rules can reduce the application of Article 8 to workplace communications to zero.

The indication that Article 8 can be applicable where there is no reasonable expectation of privacy is welcome, as the reasonable expectation test is not an adequate tool for determining the scope of the right. One problem with using reasonable expectations as the touchstone for Article 8 engagement is that people living in societies where intrusive technologies are prevalent, or surveillance is widespread, are likely to have lower reasonable expectations of privacy, thus narrowing the scope of protection provided by Article 8 . This lower level of protection might itself encourage greater use of privacy-invasive technologies, or reinforce the perception that people cannot expect to have their privacy protected, thereby reducing people's reasonable expectation of privacy even further. Applying a purely empirical reasonable expectation test therefore creates the possibility of a downward spiral in the scope of protection provided by Article 8 . Another, related, problem with the reasonable expectation test is that the state or other powerful parties may be able to create conditions where there is little reasonable expectation of privacy and so narrow the scope of Article 8. A government might do this by introducing policies of widespread surveillance, or legal frameworks which do not respect the right to private life. The unequal power relationship that exists between employer and employee creates another instance of this risk; the employer's power to set the content of the employment contract or company rulebook allows them to shape an employee's expectations of privacy. ${ }^{36}$ It should not be possible for either the state or employers to prevent

\footnotetext{
${ }^{36}$ G. Morris, 'Fundamental Rights: Exclusion by Agreement?' (2001) 30 IL 49; M. Ford, 'Two Conceptions of Worker Privacy' (2002) 31 IL 135; M. Freedland, 'Privacy, Employment and the Human Rights Act 1998' in K.S. Ziegler (ed), Human Rights and Private Law: Privacy as Autonomy (Bloomsbury Publishing 2007).
} 
the application of Article 8 in this way. Applying the reasonable expectation test in an empirical manner in the employment context allows employers to effectively abolish their employees' right to private life at work. The majority in Barbulescu were clearly alive to this danger, which is why they expressly state that it is not possible for employers to reduce the application of Article 8 to zero by setting restrictive internal rules.

Given these problems with the reasonable expectations test, the finding in Barbulescu that such expectations are not necessary for Article 8 to be engaged is a positive development. Unfortunately however, Barbulescu does not provide much guidance for determining when Article 8 will be applicable in future cases where there is no reasonable expectation of privacy. So although English courts should now look beyond the reasonable expectations test when considering whether Article 8 is applicable, it is not yet clear what additional factors they should consider, or what weight these should be given. For example, it is possible that in Barbulescu the Court were willing to find that Article 8 was applicable because of the particularly intimate content of the messages, or because the case was related to correspondence and the text of Article 8 does not qualify the scope of its protection to 'private' correspondence. The Court might not have found that Article 8 was engaged if the messages were less personal, or if the surveillance was unrelated to correspondence. This uncertainty will remain until future cases build upon Barbulescu and develop a clearer framework of when Article 8 is engaged in the absence of a reasonable expectation of privacy. One option would be to apply a more explicitly normative version of the reasonable expectations test, which asks whether an individual should be entitled to expect his privacy would be respected in the circumstances. Of course, the Court would still have to draw out the relevant factors that 
determine when people are entitled to this expectation, but it would at least solve the problems identified above.

\section{Workplace monitoring and unfair dismissal}

In this final section I will briefly consider the significance of Barbulescu for unfair dismissal claims, as this is the context in which the case was originally raised in the Romanian courts. Barbulescu breaks new ground by recognising an irreducible core to the right to private life in the workplace, which does not depend on an employee's reasonable expectations and cannot be eliminated by internal company policies. The finding that states have a positive obligation to protect employees' Article 8 rights from disproportionate interference by employers is also significant, particularly as the Court's reasoning may be equally applicable to other Convention rights that generate positive obligations. However, the impact of the case on the English law of unfair dismissal is unclear.

In cases of unfair dismissal the Employment Tribunal must decide first whether there is a potentially fair reason for dismissal, and then whether the decision to dismiss was fair in all the circumstances. ${ }^{37}$ The test for fairness is whether the dismissal falls within the band of responses that was open to a reasonable employer..$^{38}$ In $X \vee Y$ Mummery J set out the suggested approach that tribunals should take to answering this question when human rights are implicated in unfair dismissal cases;

\footnotetext{
${ }^{37}$ Employment Rights Act 1996, s.98; S. Deakin and G. Morris, Labour Law (Hart Publishing 2012) 5.62-5.154.

${ }^{38}$ Iceland Frozen Foods v Jones [1983] ICR 17 (EAT).
} 
(1) Do the circumstances of the dismissal fall within the ambit of one or more of the articles of the Convention? If they do not, the Convention right is not engaged and need not be considered.

(2) If they do, does the state have a positive obligation to secure enjoyment of the relevant Convention right between private persons? If it does not, the Convention right is unlikely to affect the outcome of an unfair dismissal claim against a private employer.

(3) If it does, is the interference with the employee's Convention right by dismissal justified? If it is, proceed to (5) below.

(4) If it is not, was there a permissible reason for the dismissal under the ERA, which does not involve unjustified interference with a Convention right? If there was not, the dismissal will be unfair for the absence of a permissible reason to justify it.

(5) If there was, is the dismissal fair, tested by the provisions of s98 of the ERA, reading and giving effect to them under s3 of the HRA so as to be compatible with the Convention right? ${ }^{39}$

Applying these principles, it initially appears that dismissals for misconduct discovered through workplace monitoring are likely to be found fair. Crucially, in cases such as Barbulescu or Atkinson the dismissal can be separated from the interference with the right to private life; the misconduct that was discovered via the interference is the reason for dismissal, not the interference itself. Monitoring cases therefore differ from those where a person is dismissed

${ }^{39}$ [2004] EWCA Civ 662 at [64]. 
for acts in their private life ${ }^{40}$ or where the dismissal itself counts as an interference with private life ${ }^{41}$ After Barbulescu, a dismissal based on workplace monitoring will fall within the ambit of Article 8, and is more likely to be classed as an unjustified interference with this right. However, at the fourth stage of Mummery's framework, the tribunal will be able to identify a permissible reason for dismissal which does not involve unjustified interference with Article 8 - namely the misconduct. Dismissing an employee for misconduct is then likely to be found fair at the fifth stage, leading the court to conclude that the dismissal is fair regardless of the disproportionate monitoring.

Despite this analysis, there are several ways employees may still be able to succeed in unfair dismissal claims where they have been monitored in a manner incompatible with Barbulescu. First, there is a chance that disproportionate monitoring prior to a dismissal could lead the courts to find the dismissal is unfair for procedural reasons. In Polkey v A.E. Dayton Services Lord Bridge held that in the case of misconduct, the employer will normally not act reasonably unless he investigates the complaint of misconduct fully and fairly'. ${ }^{42}$ There is a strong case that disproportionate monitoring constitutes a failure to investigate the matter fairly, meaning the dismissal should be found unfair. ${ }^{43}$ Second, it is possible that the tribunal

\footnotetext{
40 n 41 above; Pay v UK [2008] ECHR 1007.

${ }^{41}$ IB v Greece ECtHR 1 Jan 2013; Volkov v Ukraine [2013] ECHR 288; Sidabras v Lithuania (2006) 42 EHRR 6; $R$ (Wright and others) v Secretary of State for Health and another (2009) 2 WLR 267 (HL); The Queen on the Application of David Crompton v Police Crime Commissioner for South Yorkshire and others [2017] EWHC 1349 (Admin). 
will find that evidence gained from monitoring is inadmissible. This would make it more difficult for an employer to prove misconduct, and therefore boost the prospects of the employees' claim. However, it is unclear whether monitoring evidence will be inadmissible, as this is not required by the ECtHR jurisprudence ${ }^{44}$ and UK courts and tribunals have previously taken a permissive approach to admitting surveillance evidence. ${ }^{45}$

Finally, where there has been no misconduct discovered by the monitoring an employee may be able to resign and claim constructive dismissal. ${ }^{46}$ Employers whose workplace monitoring fails to meet the standards set out in Barbulescu could be in breach of the implied contractual term to not 'without good and proper reason act in a manner calculated or likely to destroy mutual trust and confidence' with their employees ${ }^{47}$ If this is the case, the employee is entitled to resign and bring a claim for unfair dismissal, which will succeed if the court concludes that the employer acted outside the range of responses open to a reasonable employer. In principle, it seems that an employer who monitors employees without adequate respect for the right to private life should be found to be acting outside the range of reasonable responses available to them, meaning the constructive dismissal claim should succeed. But this is complicated by the fact that the term of mutual trust and confidence is only breached when an employer acts without good and proper reason. Employers may therefore be able to argue that there has been no breach of the implied term because they were acting with a proper cause, for example

\footnotetext{
${ }^{44}$ Vukota-Bojić v Switzerland ECtHR 18 Oct 2016; Benediktsdóttir v Iceland [2009] ECHR 1100.

45 Jones v University of Warwick [2003] EWCA Civ 151; Avocet Hardware v Morrison [2003] All ER (D) 126 ; but cf Chairman and Governors of Amwell View School v Dogherty [2007] IRLR 198 EAT.

${ }^{46}$ See Deakin and Morris n 39 above, 5.69-5.72.

${ }^{47}$ Malik v Bank of Credit and Commerce International [1997] UKHL 23.
} 
investigating suspected wrongdoing, or checking compliance with company policies. If accepted by the court this would prevent employees from bringing constructive dismissal claims in response to workplace monitoring.

In sum, the outcome of unfair dismissal claims in circumstances such as Barbulescu is uncertain under English law. Dismissals for misconduct discovered via disproportionate monitoring may well be fair, unless the court finds that they are unfair for procedural reasons or the evidence gathered from monitoring is inadmissible. Where monitoring is discovered by an employee before they are dismissed they should be able to claim for constructive dismissal, unless the employer is able to demonstrate they were acting with reasonable and proper cause. This lack of clarity makes it difficult to assess whether the law is consistent with the obligation to protect Article 8 at work as envisaged in Barbulescu. However, there are at least two areas of potential inconsistency. First, it is not immediately obvious how the law of unfair dismissal can accommodate the careful balancing exercise required by Barbulescu. It may be that the courts can conduct the balancing exercise at stage three of Mummery's suggested approach in $X \mathrm{v} Y$, when they must determine whether the interference is justified. Alternately, if the courts consider workplace monitoring as part of their assessment of procedural unfairness they may be able to undertake the balancing exercise at this point. At least in principle therefore, it is possible for the courts to strike a fair balance in accordance with Barbulescu. The second issue is whether it would be inconsistent with the Convention were the UK courts to find dismissals in circumstances such as Barbulescu fair, as appears possible under $X \vee Y$. There is not space to consider this important question here, but following Barbulescu there is undoubtedly a need to closely scrutinise those areas of law that 
protect the right to private life at work, including unfair dismissal, to determine whether they are compatible with the state's positive obligations under the Convention.

\section{Conclusion}

In Barbulescu the ECtHR found for the first time that Article 8 imposes positive obligations on states to introduce protections against disproportionate workplace monitoring by private companies, and set out the principles that domestic legal frameworks must adhere to when striking the balance in this area. The case also establishes that Article 8 can be applicable in the workplace even where it is not possible to establish a reasonable expectation of privacy, thus preventing employers from using their superior bargaining power to block the application of the right. It is, therefore, a significant decision which develops and clarifies the ECtHR's jurisprudence on privacy at work and positive obligations. However, by failing to clarify the factors which lead to Article 8 being engaged where there is no reasonable expectation of privacy, the case leaves the scope of the right uncertain. Furthermore, despite being a victory for employee privacy, the impact of the decision on unfair dismissal cases involving disproportionate monitoring is unclear. 